\title{
Femtomol Single-DNA Molecules Analysis by Electro Field Strength in a Microfluidic Chip Using TIRFM
}

\author{
Seong Ho Kang," Seokjin Jeong, Dackwang Kim, Yan He, ${ }^{+}$and Edward S. Yeung" \\ Deparment of (hemisty. (honbuk National thiversity, foomu 561-756, Korea. "li-mail: shkang@chonbukac.kr

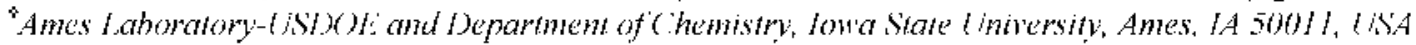 \\ Received october 25, 2004
}

Key Words : Single-molecule detection, Microchip, TIRI:M

Microchip techniques such as the micro total analysis system $(\mu-\mathrm{T} \Lambda \mathrm{S})^{1}$ or lab-on-a-chip ${ }^{2}$ lave been developed, practically in the microlluidics ficlds. Microfluidics has enabled many developments in chemical analysis of biomolecules including high-specd separation, high-throughput. parallel assays, and microscalc sample preparation. ${ }^{3}$ Recently, microchip electrophoresis (ME), which uses various microlluidic chips, has become a powerlul and effective analytical technique for DNA analysis, due to its analytical throughput, speed, small reagent volume, automation, minialurization, and high resolution." The most signilicant advantage of $\mathrm{MI}$ in DNA analysis is its high speed compared to conventional slab gel electrophoresis. However, although MF provides a tast analysis, a major limitation of $\mathrm{MF}$. analysis is a small sample volume that causes low concentration sensitivity.

Single-molecule detection (SMD) techniques with a high sensitivity have recently attracted plenty of attention in the field of life science. ${ }^{5}$ The observation and manipulation of single biomolecules allow their dynamic belaviors to be studicd to provide insight into molccular yenctics, ${ }^{6-8}$ biochip assembly, ${ }^{1-12}$ biosensor design, ${ }^{1.3-15}$ DNA biophysics ${ }^{\mid 6-3(1)}$ and basic separation theories of capillary electrophoresis and liquid chromalograply. ${ }^{31-37}$ Nlhough the major advantage of SMD is the ability to observe specics that present at low concentrations in biomaterials, a recent SMD study demands an ultra-sensitive sample detection system in solution. However, the major problem to overcome when individual biomolecule in an aqueous solution is the luge amount of background noise, which can be caused by Raman scattering from water molecules, incident light, luminescence from the objective lens, and dust. ${ }^{5}$

Total internal rellection microscopy (TIRFM) is an optical technique used to observe single molecule fluorescence. $\Lambda$ fter single fluorophores in an aqueous solution were first observed in 1995 using TIRFM and conventional inverted fluorescence microscopy, ${ }^{2 i}$ some bioplysicists and chemists have used the TIRFM teclinique for many years, while others are just beginning to explore the boundaries of this versatile mechanism for sludying phenomena occurring at interfaces.

In our TIRFM application of a microchip, the cvanescent ficld layer (ГF. . ) was formed when the incident beam was totally reflected by the interface between the nun buffer solution and the surface of microchip. We applied the microchip to an FFI, which can detect fluorescently labeled DNA molecules, and which is based on the principle of the TIRFM. The EFL is not restricted to the diffraction limit of light, ${ }^{5.11}$ thus it could be localized close to the microchip surface, which resulted in the penetration depth $(\sim 150 \mathrm{~nm})$ being several-fold shorter than the wavelength of light (Figure 1). Therefore, the illumination was restricled to a complex fluorescent DNA sample cither bound to the microchip inner surface or located in the microchip, thereby reducing the background light. This effect leads to images of high contrast having an excellent signal-to-noisc. We demonstrated the detection of different size single-DNA molecules (i.e., $48.5 \mathrm{~kb}$ DN $\Lambda$ and $5.4 \mathrm{~kb}$ DN $\mathrm{N}$ ) by TIRFM
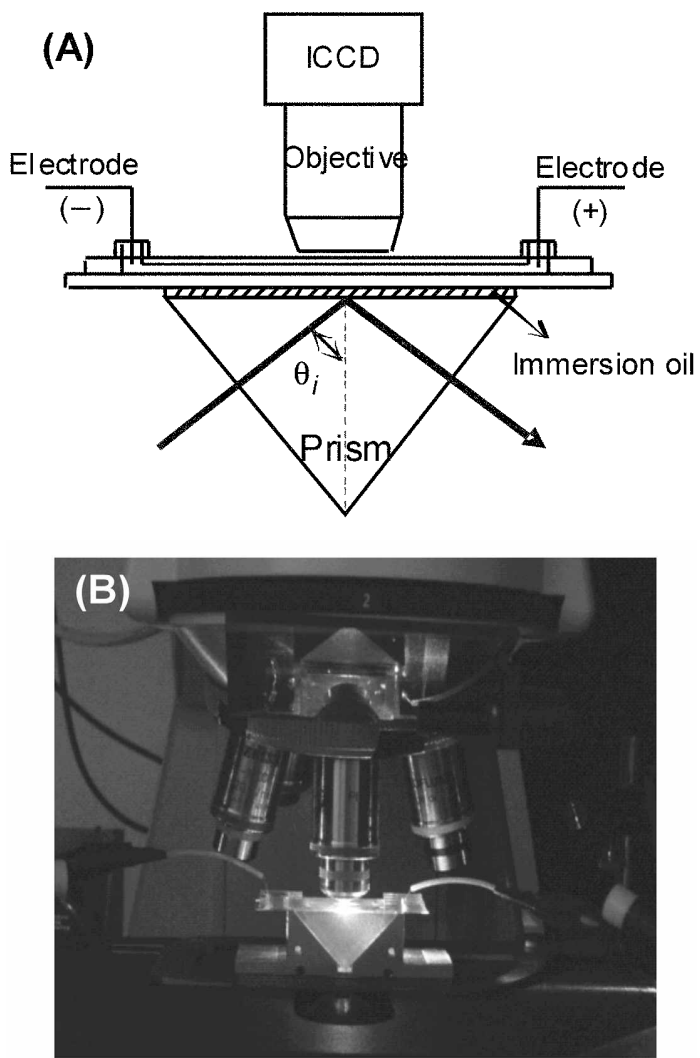

Figure 1. (A) Schematic diagram and (B) picture of TIRFM experiment setup at the PDMSiglass microfluidic chip for singleINNA molecule monitoring within the evanescent field layer. 


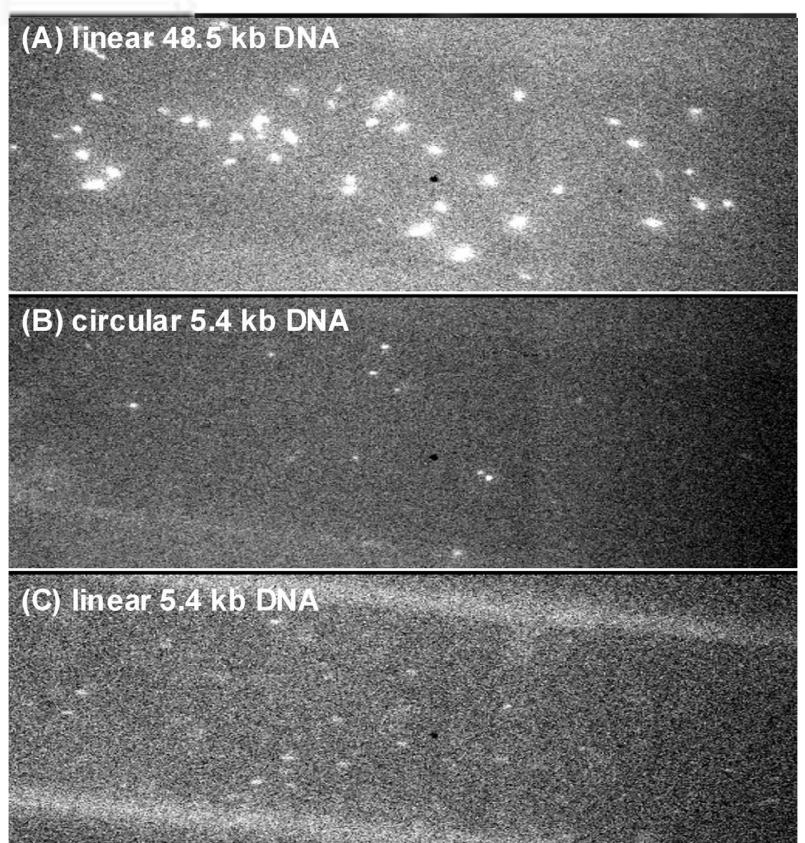

Figure 2. Video images showing the shape of (A) $48.5 \mathrm{~kb}$ DNA, (B) circular $5.4 \mathrm{~kb}$ DNA molecules and (C) linear $5.4 \mathrm{~kb}$ DNA molecules in the PDMS/glass microchip. Run buffer solution, $0.25 \% \mathrm{C}_{10} \mathrm{E}_{6}$ in $10 \mathrm{mM}$ Gly-Gly buffer $(\mathrm{pH} 8.2)$, applied electric field. $40 \mathrm{v} / \mathrm{cm}$. DNA sample concentration, $100 \mathrm{fM}$. ICCD exposure time. $10 \mathrm{~ms}$; frame rate, $5 \mathrm{II}$; laser power, $50 \mathrm{~mW}$.

and the manipulation by the clectric ficld strenglh in a PDMS/glass microchip (Figure 2). The video images of flowing individual DNA molecules in the mixture of $48.5 \mathrm{~kb}$ $D \wedge \wedge$ and circular $5.4 \mathrm{~kb}$ DN $\wedge$ (Figure 3) were also well distinguished in the microchip as well as in cach pure singleDNA molecules (Figute 2). The migration velocities of different size DNA molecules as a function of the electric field in the PDMS/glass microchip are shown in Figure 4. The TIRFM technicue was successfully applied to follow real-time dynamic behavior of the individual DNA moleculcs as the ultra-sensitivity of femtomol ( $\mathrm{PM}$ ) concentration level in the microchip. The migration velocity was recorded for 50 molecules from each data set. Over an electric field strength of $25 \mathrm{~V} / \mathrm{cm}$, the velocities of both linear type DNA molecules (linear $5.4 \mathrm{~kb}$ D.NA and $\lambda$-D.NA) were consistently increased as field strength increased. However.

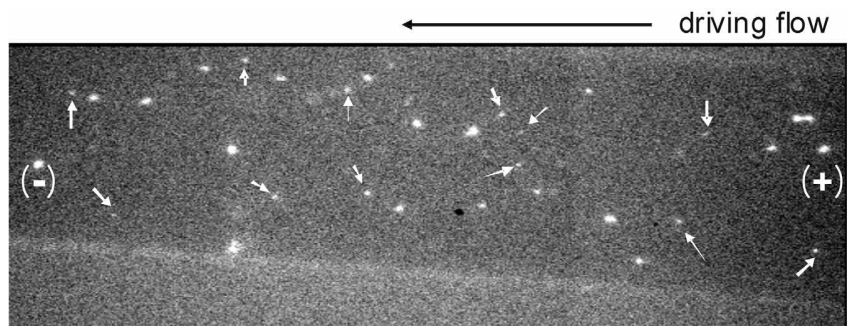

Figure 3. Video inages of the DNA mixture sample (circular 5.4 kb DNA molecules and $48.5 \mathrm{~kb}$ D.A molecules) at the PDMS glass microchip. Experiment conditions were the same as those in Figure 2. "Arrows indicate the individual circular $5.4 \mathrm{~kb}$ DNA molecules

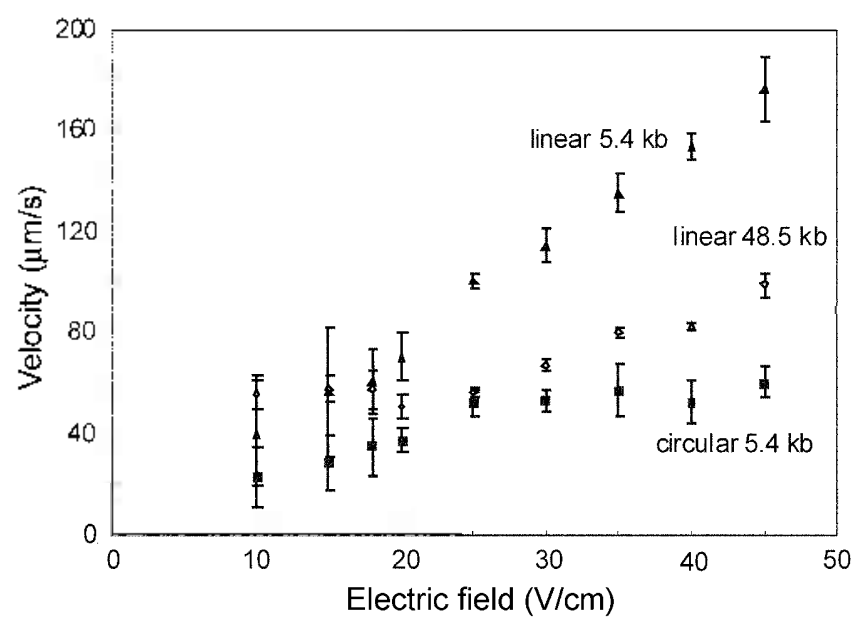

Figure 4. The migration velocities of the different size D.AA molecules as a function of the electric field in the PDMS/glass microchip. The experiment conditions were the same as those in Figure 2. Solid triangles: linear $5.4 \mathrm{~kb}$ D $\times \mathrm{A}$. Solid squares: circular $5.4 \mathrm{~kb}$ DNA. Open circles: $48.5 \mathrm{~kb}$ DNA

the velocity of circular DNA molecules was not in proportion to the field strength. Because the liner DNA molecules have a stretched-fon under a high electric field $(\geq 25 \mathrm{~V} / \mathrm{cm})$ and the molecules have a weak steric hindrance at the sieving medium, while the circular 5.4-kb DNA molecules still have only the circular form. So, the DNA molecule is fasier than the circular DNA molecule above 30 $V / \mathrm{cm}$ and the buffer condition. This phenomena indicated that the shape of DNA molecules have an influence on the migration velocity of DNA in the microchip. The calculated migration velocily of the lincar $5.4 \mathrm{~kb}$ DN $\mathrm{A}$ molcculc in the microchip showed the highest velocity in the range of $20-45$ $\mathrm{V} / \mathrm{cm}$. It was possible to distinguish $5.4 \mathrm{~kb}$ DNA from 48.5 $\mathrm{kb}$ DNA on the basis of electrophoresis at the singlemolecule level with almost no doubt.

To summatize, we demonstrated a single-DNA molecule detcclion method in a microfluidic chip by TIRFM that allows single DNA molecules of different sizes to be screened at a time based on their migration velocity. Since the measurement only depends on being able to follow a molecule for a few milliseconds in the solution, the different size DNA molecules can be analyzed within a few seconds and will an ultra-sensilive decection intensily as $\mathrm{CM}$ level.

\section{Experimental Section}

Chemicals. Gly-Gly, $\mathrm{C}_{16} \mathrm{E}_{0}$ and sodium hydroxide were A.C.S. grade purchased from Signa Chemical Co (St. Louis, MO, USA). A $10 \mathrm{~m} . \mathrm{M}$ aqucous solution of Gly-Gly was prepared, and the $\mathrm{pH}$ was adjusted to 8.2 with the addition of $1 . \mathrm{M} \mathrm{NaOH}$. All buffer solutions were filtered through a $0.2-$ $\mu \mathrm{m}$ filicr and left for photo-blcaching overnight with a UV-B lamp (G15T8E, 280-315 nm. Hansung Ultraviolet Co., Ltd., Korea). The rum buffer was $0.25 \% \mathrm{C}_{16} \mathrm{E}_{13}$, dissolved in the 10 mM Gly-Gly buller ( $\mathrm{pH} 8.2$ ). The nonionic surfactant, $\mathrm{C}_{16} ; \mathrm{F}_{4}$ was used as a sieving matrix for the separation of DNA 
fragments. $^{38}$

DNA Samples Preparation. $\lambda$-DNA (48 502 bp). $\Phi X 174-$ DNA (5 $386 \mathrm{bp}$ ) and others DNA samples were obtained from Promega (Madison. WI, USA). All DNA samples were prepared in a $10 \mathrm{mM}$ Gly-Gly buffer. DNA samples at a concentration of $200 \mathrm{pM}$ were labeled with an intercalating dye YOYO-I (Molecular Probes, Eugene, OR, USA) at a ratio of one dye molecule per five base pairs according to the manufacturer's instructions. DNA samples labeled with YOYO-I were allowed to incubate for $5 \mathrm{~min}$ before further dilution and use. For the single-molecule inaging experiments. these DNA samples were further diluted to $1-100 \mathrm{fM}$. prior to the start of the experiment.

Microscope and CCD Camera for Microfluidic Chip. A Pentamax 512-EFT/IEIA intensified CCD (ICCD. Princeton Instruments. Princeton. NJ, USA) camera was mounted on top of a Zeiss Axioskop2 upright microscope with a Nikon $40 \times$ Plan-fluor oil type ( 1.30 N.A. Japan). The digitization rate of the camera was $5 \mathrm{MHz}$ with software controller gain set at 3 , and a hardware intensifier gain set at 80 . The camera was operated in the external synchronous mode with the intensifier disabled open, and was also used in the frametransfer mode. The excitation source was a wavelength tunable argon ion laser (out power $150 \mathrm{~mW}$ at $488 \mathrm{~nm}$ : model 35LAP431-220. Melles Griot, Iriin, CA. USA). which was used as the excitation bean. A Zeiss Filter set No. 09 was used. A Uniblitz mechanical shutter (model LS2Z2. Vincent Associates, Rochester, NY. USA) was used to block the laser beam when the camera was off in order to reduce photo-bleaching. The shutter was controlled by a model VMM-Dl shutter driver. The experimental timing was controlled with a DG535 four-channel digital delay/ pulse generator (Stanford Research Systems. Inc.. Suntyvale, CA, USA). The ICCD camera was triggered at a time of 0Ins with 10-ms duration TTL pulse. The sampling frequency was $5 \mathrm{~Hz}$. with the shutter driver set to 10 -mis exposure and 190-1ns delay. WinView/32 software (version 2.5.14.1. Downingtown. PA) was used for DNA image collection and data processing.

Evanescent Wave Excitation Geometry. The excitation geometry was similar to that previously described (Figure 1) ${ }^{3 \leqslant, 37}$ Briefly, the microchip was placed on the hypotenuse face of a right-angle prism (Melles Griot: $\mathrm{BK} 7, \mathrm{~A}=\mathrm{B}=\mathrm{C}=$ $2.54 \mathrm{~cm}$. refraction index $(\mathrm{n})=1.516$ ). The chip and the prism were index-matched with a drop of immersion oil (Immersol $^{\mathrm{TM}} 518 \mathrm{~F}$. Zeiss. $\mathrm{n}=1.518$ ). The laser beam was directed through the prism toward the microchip/nun buffer interface. The angle of incidence $\theta_{j}$ was slightly greater than $69^{\circ}$.

PDMS/Glass Microchip Preparation for TIRFM. The microchip preparation for TIRFM is similar to that described in ref. 39. Briefly, the chip had a simple cross injector design composed of one PDMS plate (cover for microchannel. $0.26-\mathrm{mm}$ thick) and one glass plate (No. 1 Corning cover glass. $\mathrm{n}=1.523$ ). Tygon hose (I.D. $2.4 \mathrm{~mm}$. O.D. $5.5 \mathrm{~mm}$ : SAINT-GOBAIN. OH. USA) pieces were cut to orifice at the end of each channel and immobilized with UV epoxy' for the sample and run buffer reservoirs. The channel dimension was $50-\mathrm{mm}$ long. $50-/ \mathrm{m}$ wide and $50-/ \mathrm{m}$ deep. The reservoirs were $2.0 \mathrm{~mm}$ in diameter and $1.76-\mathrm{mm}$ in total depth. A PDMS/glass microchip was placed on the prism with the index-matched with immersion oil ( $\mathrm{n}=$ $1.518)$.

Acknowledgements. The authors wish to thank the research team of the Center for University-Wide Research Facilities (Chonbuk Natl. Univ.) for their assistance with instrumentation, and Ji-Young Lee at Iowa State University for fruitful discussions. This work was supported by the Korea Research Foundation Grant (KRF-2003-002-C00189).

\section{References}

1. Harrison. D. J: van den Berg. A. Mficro Total Anatysis Systems 98: Kluwer Academic Publishers: Dordrecht. 1998.

2. Graves. D. T. Trends Biotechnol 1999. 17. 127.

3. Ropper. M. G.: Shackmant. J. G.: Dahlgren. G. M.: Kennedy. R. I. Anal. Chem. 2003, 75. 4711.

4. Doadislav. D.: Lill. S.: Tovanowich. S. Electrophoresis 2000. 21. 41

5. Ishijima, A.; Yanagida. T. Trends Biochem. Sci. 2001. 26, 438

6. Herrick. I.: Michalet. X.: Conti. C.: Schurra. C.: Bensimon. A Proc. Natl Acad Sci. tlSt 2000. 97. 222.

7. Herrick. T.: Bensimon. A. Chronosome Res 1999. 7. 409

8. Lyubchenko. Y. L.: Shlyakhtenko. L. S. Proc. Nall. Acad Sci. (USA) 1997.94. 496.

9. Hill. E. K.: de Mello. A. J. Anatyst 2000. 125. 1033.

10. Turner, S. W. P. Levene, M.; Korlach. J.: Webb. W. W. Craighead, H. G. Procee dings mT.AS 2001 Sumposium: 2001: p 259.

11. Yoshinobu. B.. Proceedings of the HTAS Smposimn: 2000: p 467.

12. Shivashankar. G. V: Libchaber. A. Current Science 1999. 76. 813.

13. Chan. V.: McKenzie, S. E.: Surrey. S.; Fortina, P.: Graves, D. J. $d$. Colloid Interface Sci. 1998. 203. 197.

14. Chan. V.: Graves, D. J; Fortina. P; McKenzie. S. E. Lamgmii 1997. 13, 320

15. Jordan. C. E.: Frutos. A. G.: Thiel. A. J.: Corn. R. M. Anal Chen. $1997.69,4939$.

16. Bensimon. A.: Simon. A.: Chiffaudel. A.: Croquette. V: Heslot. F.: Bensimon. D. Science 1994. 265. 2096.

17. Bensimon, D.: Simon, A. J.; Croquette. V.: Bensimon. A. Plnus. Rev: Lett. 1995. 74. 4754

18. Xue. Q.: Yeung, E. S. Nature 1995, 373.681

19. Houseal, T. W.: Bustamante. C.: Stump, R. F.: Maestre, M. F. Biophs. J. 1989. 56.507.

20. Auzanneau. I., Barreau, C.; Salome, L. C. R. Acad Sci., Ser $M$ 1993. 316. 459 .

21. Strick. T. R.: Allemand. J.-F.: Bensimon. D.: Croquette. V. Biophns. J. $1998,7+2016$.

22. Fan1. F.-R. F.: Bard. A. J. Science 1995. 267.871

23. Funatsu, T; Harada, Y:; Tokunaga, M.: Saito. K: Yanagida, T. Nature 1995, 374.555.

24. Chiu. D. T.: Zare. R. N. J. Ant Chem. Soc. 1996. 118.6512.

25. Nie. S.: Chiu. D. T.: Zare. R. N. Science 1994, 266. 1018

26. Yokota. H.: Saito. K: Yan1agida. T. Phys. Rev Lett. 1998. 80. 4606.

27. Enderlein, J. Biophus. J. 2000, 78. 2151

28. Xu. X.-H.: Yeung. E. S. Science 1997. 276. 1106.

29. Dickson, R. M: Norris. D. J.: Tzeng, Y.-L.; Moerner, W. E Science 1996. 27t, 966.

30. Ma. Y: Shortreed. M. R: Yeung. E. S. Anal Chent 2000. 72. 4610 . 
31. Xu. X.-H. N.: Yeung. E. S. Science 1998. 281. 1650.

32. Shorted. M. R.: Li. H.: Huang. W.-H.: Yeung. E. S. Anat. Chent. 2000. 72,2879

33. Smith. S. B.: Aldridge. P. K.: Callis. J. B. Science 1989. 2-13. 203.

34. Ueda, M. J. Biochem. Bioplys. Methods 1999. 41. 153.
35. Kang. S. H.: Shortreed. M. R.: Yeung. E. S. Anal Chent 2001. 73. I09!.

36. Zheng. J.: Yeung, E. S. Anal Chem. 2002. 74. 4536

37. Kan1. S. H.: Yeung. E. S. Anal Chem. 2002. 7t. 6334

38. Wei, W. Yeung, E. S. Anal. Chem. 2001. 73. 1776.

39. Kang. S. H.: Lee. S: Yeung, E. S. Anal Chem 2004, 76. 4459. 